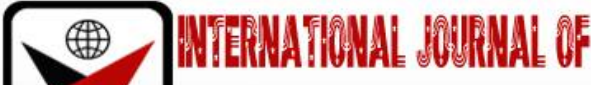

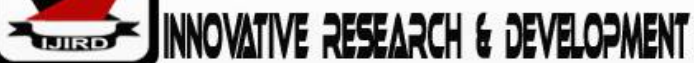

ISSN 2278-0211 (Online)

\section{Effect of Treasury bond on Economic Development of Rwanda}

\author{
Jerome Ndagijimana \\ Post Graduate Student, School of Business Studies, \\ Jomo Kenyatta University of agriculture and Technology, Kenya \\ Dr. Patrick Mulyungi \\ Lecturer, School of Business Studies, \\ Jomo Kenyatta University of agriculture and Technology, Kenya
}

\begin{abstract}
:
Treasury bonds are an important component of a country's financial system and represent a critical component of National Bank of Rwanda monetary policy. The purpose of this study was to examine the effect of Treasury bond market development on economic growth in Rwanda Stock Exchange. The target population of this study was 12 employees dealing and working with Rwanda Stock Exchange. The study adopted an open-ended questionnaire for data collection. Data was processed and analyzed using SPSS computer-based software version 21. Results from the study showed that investors strongly appreciated the profit they get from Treasury bond. Further the Results revealed that Treasury bond is the most significant in explaining the economic development of Rwanda with a significance of 0.000 which is less that a $p$-value of 0.05 and beta value is 0.728 . Pearson correlation coefficient, $(r=0.728)$ shows that there is a positive and high correlation relationship between stock market and economic development where the P-value $(0.000<0.05)$. From the findings, both bond market variables of size and liquidity have significant positive relationship with GDP. It can therefore be concluded that Treasury bond market development has a significant positive effect on economic growth in Rwanda. The study recommends that the Capital Markets Authority should also hasten the introduction of the new products into the capital markets such as derivative instruments (bond options, futures, swaps) and have necessary regulatory framework in place to make the bond market even more vibrant.
\end{abstract}

Keywords: Treasury bonds, economic development, growth

\section{Background}

Globally, treasury bonds have been used as a means of raising capital (Jensen, 2015). For instance, the global financial crisis that occurred in 2007-2008 significantly increased the importance of the bond market as a source of finance as corporate shift from overreliance on bank debt and increased government borrowing (Mussa \& Kihongo, 2011). Developed countries such as the United States of America (US) have the largest, the best and the most developed bond market in the world (Becker \& Ivashina, 2011). The US bond statistics indicates that the bond market is dominated by the developed countries. The US accounted for 39\% of the world value of outstanding domestic bonds; its market is well diversified with products such as mortgage backed securities, federal agency securities, corporate and treasury bonds (BIS, 2012). It is followed by Japan (18\%). United Kingdom (UK) and emerging markets follow closely (IMF, 2011).

The Treasury bond market is a very large and liquid trading market. Its uptake looks at the subscription rates of issued bonds and is highly influenced by the market liquidity. Treasury securities are one of the safest income-earning investments although they pay usually pay lower rates of interest than other investment choices such as stock market. Governments borrow money through bonds to finance their treasury and promise to repay this money plus an interest rate at a fixed time (maturity). Treasury bonds are important for a variety of public policies ranging from taxation issues and financial regulation. A government running a deficit finances its budget by floating treasury bonds (Ndung'u, 2013).Evidence indicates that, while most Stock markets in African countries are relatively underdeveloped, those countries which introduced reforms that are geared towards development of Stock markets have been able to grow at relatively higher and sustainable rates (Perkins \& Block, 2012).

The East African bond market is dominated by treasury bonds and is significantly underdeveloped (Kibua et al., 2015). As compared to other EAC member countries, the Kenyan bond market is the largest and most developed. Beyond the EAC, financial markets in the Sub Saharan Africa (SSA) countries are shallow, and have inadequate access to finance (Adelegan \& Radzewicz-Bak, 2013). Treasury bonds are an important component of a country's financial 
system and represent a critical component of central banks' monetary policy. They act as a bench mark interest rate and form part of the yield curve, which conveys important information for monetary policy (Biepke, 2014). Markets are said to be efficient if they quickly and correctly incorporate information into prices. This is important because many traders are unable to devote time and resources to gathering information given the cost this portends for them, preferring instead to depend on the market itself to properly reflect all available information in prices.

Nowadays government of Rwanda use Treasury bond as one of the sources of government budget for financing the government infrastructures development, $100 \%$ of respondents were strongly appreciated. Those who invested in TB they get profit twice a year, after six months. Currently many big projects of Rwanda Government were financed by the issues of Treasury bond and Euro bond. In 2013 Government of Rwanda issued the Euro bond of $\$ 400$ million in order to finance the big infrastructure projects, e.g.: Convention Center, Nyabarongo hydro power and buying new Airplane of RwandAir (BNR, 2015).

On April 25th 2013, Rwanda completed the issuance of a 10-year $\$ 400 \mathrm{~m}$ on Irish Stock exchange market the first of its kind in East Africa. The bond was highly over-subscribed and priced to perfection. The bond which carries a coupon (price) of $6.625 \%$, recorded large order book with a total subscription of $\$ 3.5$ billion, more than 8.5 times over and above the intended amount of $\$ 400$ million with over 250 investors across the globe participating (MINECOFIN, 2013)

\subsection{Statement of the Problem}

Treasury bond market in Rwanda has become vibrant acting as a key source of funding for key infrastructure projects and for continuous economic growth and development (CMA, 2012). For continuous growth and developmentestablishment of a stock market in Rwanda has been one of the major initiatives taken by the Government to mobilize resources CMA, (2012). However, in recent years Rwandan stock market has been described as narrow and shallow limited literature exists on Treasury bond in Rwandan context save for (Kazarwa, 2015). The question of the influence of treasury bonds on economic development in Rwanda Stock Exchange is thus not yet well documented.

\section{Literature Review}

\subsection{Theoretical Framework (Classical Theories of Economic Development)}

The first generation of economic development models was formulated in the early years after the World War II. These early models focused on the utility of massive injections of Stock to achieve rapid GDP growth rates. The two famous models are Rostow's stages growth model and the Harrod-Domar model (Todaro \& Smith 2013).

Theorists of the 1950s and early 1960s viewed the process of development as a sequence of historical stages. This view was popularized by Rostow (Ingham, 2015). Building on the historical pattern of the then developed countries. The transition from underdevelopment to development would pass through five stages: the traditional society, the preconditions for take-off, the take-off, the drive to maturity and the age of high mass consumption. The decisive stage is the take-off, through which developing countries are expected to transit from an underdeveloped to a developed state. Increasing rate of investments is considered to be necessary to induce per-capita growth. Like Rostow's stages growth model, the Harrod-Domar model emphasized that the prime mover of the economy is investments (Ghatak, 2013). Every country therefore needs Stock to generate investments. The principal strategies of development from the stage approach were commonly used by developing countries in the early post-war years. With a target growth rate, the required saving rate can then be known. If domestic savings were not sufficient, foreign savings would be mobilized.

Although Rostow (2011), were right about the important role of investments that is most closely correlated with the economic growth rate, this is not the only condition for a country to develop. The key weakness of these models lies in their simplifying assumptions. A single production function is simply assumed for all countries (Adelman 2010). Every economy is assumed to have the same necessary conditions and would pass through the same phasing, stage by stage. But that economic growth path, which historically had been followed by the more developed countries, is not the only one pathway. The development process is actually highly nonlinear (Levine\&Zervos, 2014). Economies may miss stages, or become locked in one particular stage, or even regress depending on many other complementary factors such as managerial capacities, and the availability of skilled labour for a wide range of development projects (Todaro \& Smith 2014).

The empirical results revealed that, although the causality between treasury bonds on economic development in Rwanda Stock Exchange is a sensitive to the choice of measure for financial development, on balance the demand following response tends to predominate.

\subsection{Treasury Bonds on Economic Development}

Onwumere et al (2012) conducted a study on stock market development and economic growth in Nigeria using the demand-following hypothesis. They used time series data from the period 1996-2010. Using Ordinary Least Square (OLS) regression, their findings indicated that economic growth had positive and non-significant impact on market capitalization ratio and turnover ratio of the Nigerian stock exchange but had a negative on the 
Nigerian stock market value traded ratio. Their study however falls short on testing for causation, while correlation may imply that the growth of the economy has high correlation with capital market development indicators, it does not necessarily mean that there is causation. Their study also falls short of controlling for other variables that may affect the economic growth and capital market indicators.

Ngugi and Afande (2015) analyzed the microstructure characteristics of the Kenyan bonds market and the factors influencing these characteristics. Their results showed that the Kenyan bond market had weak microstructure characteristics. These characteristics 25 though differed across the Treasury and corporate bonds and also across the maturities. Treasury bonds were more liquid with higher traded value and more traded days as compared to the corporate bonds. However, the corporate bond market was less volatile. The Treasury bonds returns had a higher volatility for the longer tenors than the short tenor hence the preference for short tenor bonds. In explaining this they found that there were various institutional gaps, for example: no credit rating agencies, primary dealers and underwriting services, stringent listing requirements and no single model for determining prices of bonds. They concluded that to make the market work, it is crucial to address the institutional structures

Murayi (2013) examined the effect of capital market deepening on economic growth in Kenya. The finance growth nexus formed the basis of his research with the capital market assumed to have a supply leading effect on economic growth. His study, using data from 1992-2011, adopted correlational research design to identify the effect of capital market deepening variables on growth. A multivariate regression model was used to regress the independent variables against the dependent variable with the dependent variable being Real GDP of Kenya and the independent variables being Stock Market Turnover Ratio, Bond Market Turnover Ratio, Value Traded Ratio, Market Capitalization Ratio and Stock Market Size. He concluded that capital market deepening has a significant positive effect on GDP growth in Kenya and therefore lends support to the finance growth nexus.

Kapingura \& Makhetha-Kosi (2014) examined the causal relationship between bond market development and economic growth in Africa with South Africa as a case study over a period from 1995 to 2012. Quarterly data applying the Engle Granger co integration method and the pairwise granger causality test was used. Empirical results revealed bi-directional causality between GDP and bond market capitalization with the causality from bond market to GDP being stronger as compared to the reverse causality even though both were significant at $10 \%$. Their results implied that African governments should put in place policies which will promote the development of the bond market as one of the ways to mobilize domestic resources and promote economic growth.

\subsection{Conceptual Framework}

Stock market is always a risk proposition and investors are reluctant to invest in Stock market, the investors they may know the primary role of Stock market is to raise long-term funds for governments, banks, and corporations while providing a platform for the trading of securities and investors can then invest in the Stock market by purchasing those stocks and bonds. This study comprises of dependent and independent variables. These variables and their relationships are illustrated in the following Figure 1:

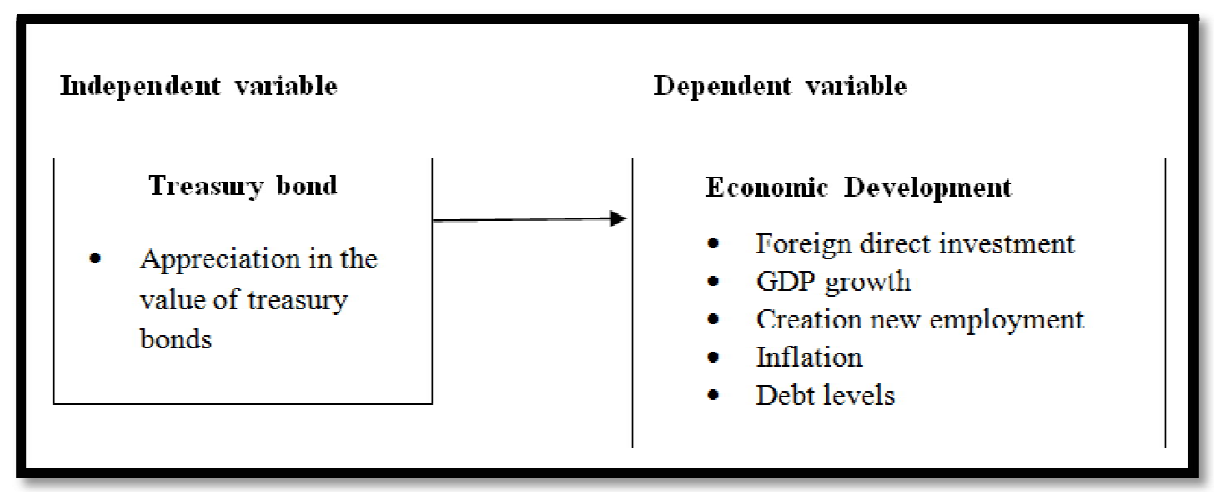

Figure 1: Conceptual Framework

\section{Research Methodology}

The study adopted descriptive research design to establish the relationship between Stock market and economic development in Rwanda. Twelve (12) employees of Rwanda Stock Exchange were purposively sampled for their knowledge in the stock exchange market to whom a structured questionnaire was administered for data collection. The data was edited, coded and finally analyzed using a computer-based SPSS 23 software for both descriptive and inferential statistics 


\section{Results and Findings}

\subsection{Role of Treasury Bonds on Economic Development}

The study investigated the role of treasury bonds on economic development in Rwanda. The study found out that Government use TB as one source of its budget deficit- with the results. This is as depicted by 4(33.3\%) who strongly agreed and $8(66.7 \%)$ who just agreed with the statement. The mean was 2.88 and the standard deviation was at 1.01 . In addition, $100 \%$ of the respondents strongly agreed that Government use TB to finance its infrastructure project and others government programs. The mean was 2.05 and the standard deviation was at 0.97 . Lastly, $100 \%$ of the respondents strongly agreed that Government of Rwanda has been financed many projects through treasury bonds. The mean was 2.70 and the standard deviation was at 1.20.

\begin{tabular}{|c|c|c|c|c|c|c|c|}
\hline Statements & SA & A & UN & D & SD & M & Std. Dev \\
\hline $\begin{array}{c}\text { Government use treasury bonds } \\
\text { as one source of its budget } \\
\text { deficit- with the results }\end{array}$ & $4(33.3 \%)$ & $8(66.7 \%)$ & $0 \%$ & $0 \%$ & $0 \%$ & 2.88 & 1.01 \\
\hline $\begin{array}{c}\text { Government use treasury bonds } \\
\text { to finance its infrastructure } \\
\text { project and others government } \\
\text { programs }\end{array}$ & $12(100 \%)$ & $0 \%$ & $0 \%$ & $0 \%$ & $0 \%$ & 2.05 & 0.97 \\
\hline $\begin{array}{c}\text { Government of Rwanda has been } \\
\text { financed many projects through } \\
\text { treasury bonds }\end{array}$ & $12(100 \%)$ & $0 \%$ & $0 \%$ & $0 \%$ & $0 \%$ & 2.70 & 1.20 \\
\hline
\end{tabular}

Table 1: Effect of Treasury Bondon Infrastructure Development in Rwanda Source: Primary Data, 2019

\subsection{Treasury Bond and Business Growth in Rwanda}

The study investigated the relationship of treasury bonds and business growth in Rwanda. The study found out that majority $8(66.7 \%)$ have already invested in TB and gets more profit while only $4(33.3 \%)$ agreed with the statement. In addition, $8(66.7 \%)$ agreed that TB pays more profit while Invested in TB is more profitable than others investment as indicated by $10(83.3 \%)$ while those who have invested in TB got profit twice a year as indicated by all the twelve respondents.

\begin{tabular}{|c|l|c|c|c|c|c|c|}
\hline Statements & SA & A & UN & D & SD & M & Std. Dev \\
\hline $\begin{array}{c}\text { Those who have already invested in } \\
\text { TB gets more profit }\end{array}$ & $4(33.3 \%)$ & $8(66.7 \%)$ & $0 \%$ & $0 \%$ & $0 \%$ & 1.55 & 0.87 \\
\hline TB pays more profit & $4(33.3 \%)$ & $8(66.7 \%)$ & $0 \%$ & $0 \%$ & $0 \%$ & 1.90 & 1.04 \\
\hline $\begin{array}{c}\text { Invested in TB is more profitable } \\
\text { than other investment. }\end{array}$ & $10(83.3 \%)$ & $2(16.7 \%)$ & $0 \%$ & $0 \%$ & $0 \%$ & 2.10 & 1.20 \\
\hline $\begin{array}{c}\text { Those who have invested in TB got } \\
\text { profit twice a year }\end{array}$ & $12(100 \%)$ & $0 \%$ & $0 \%$ & $0 \%$ & $0 \%$ & 1.58 & 0.77 \\
\hline
\end{tabular}

Table 2: Effects of Treasury bond on Business Growth in Rwanda Source: Primary Data, 2019

\subsection{Correlation Analysis between Treasury bond and Economic Development}

This section analyzed the strength and direction of relationship between the variables under study. The correlation coefficient measures the strength and direction of a linear relationship between two variables on a scatter plot. Correlation analysis was conducted to empirically determine whether Treasury bond was a significant determinant of economic development. It is important to note that at 0 , there is no correlation. At 1 there is a strong positive correlation and at -1 there is a strong negative or inverse correlation. The more the value approaches 1 the stronger the correlation and the opposite is true. After carrying the descriptive statistics, the variable was subjected to correlation analysis in order to assess the effect of Treasury bond and economic development. The findings in Table 3 revealed that the results of correlation between treasury bond and economic development was at 0.728 mean that supplier's competence was at the level of $72.8 \%$ which proves a significant relationship between treasury bond and economic development of Rwanda. The researcher considered the level of significance which is 0.05 , implying that there is a significant relationship between them because their p-value $(0.000)$ is statistically significant at $5 \%$ level of significance. 


\begin{tabular}{|c|c|c|c|}
\hline \multirow{2}{*}{} & Treasury bond & $\begin{array}{c}\text { Economic } \\
\text { Development }\end{array}$ \\
\hline \multirow{2}{*}{ Treasury bond } & Pearson Correlation & 1 & \\
\cline { 2 - 4 } & Sig. (2-tailed) & & \\
\cline { 2 - 4 } & $\mathrm{N}$ & 12 & 1 \\
\hline \multirow{2}{*}{$\begin{array}{c}\text { Economic } \\
\text { development }\end{array}$} & Pearson Correlation & $.728^{* *}$ & 12 \\
\cline { 2 - 4 } & Sig. (2-tailed) & .000 & 12 \\
\cline { 2 - 4 } & $\mathrm{N}$ & 12 & \\
\hline
\end{tabular}

Table 3: Correlation between Treasury bond and Economic Development

Source: Primary Data, 2019

\subsection{Factors Affecting Treasury bond (2015-2019)}

Using the secondary data extract from the National Institute of statistics of Rwanda different factors were tabulated on how they affect the treasury bonds in terms of economic development. Treasury bonds are issued with a minimum denomination of RFW 100,000. The bonds are initially sold through auction in which the competitive bidder sets up the price. However, there are some number of issues that affects investments in terms of treasury bonds.

From the figure 2 Rwanda's economy is estimated to have grown by 10.9 percent in the first three quarters of 2019, driven by robust performance in industry and services of the years between 2015-2019. The performance of the agriculture sector, which is the major source of Rwanda's employment, was largely in line with historical averages. Nominal GDP grew in parity with real GDP as a result of a near-zero GDP deflator in the last months of the period of the study. This has affected the uptake of the treasury bills in the country.

After decelerating in 2016 and 2017 as a result of Government's adjustment program to reverse growing external imbalances, investment picked up in 2018 and further accelerated in 2019. Investment grew by around 29 percent, y-o-y, in the first three quarters of 2019, higher than the 25 percent growth in 2018, and well above the average growth in 2016-2017 which was less than 9 percent. The surge in investments was supported mainly by public investments, which have elevated the share of gross capital formation in GDP to 26 percent, above the average of 24.1 percent in 2016-18. This has led to increased economic development as can be witnessed since majority of investors are able to buy treasury bonds which are a big component towards economic development

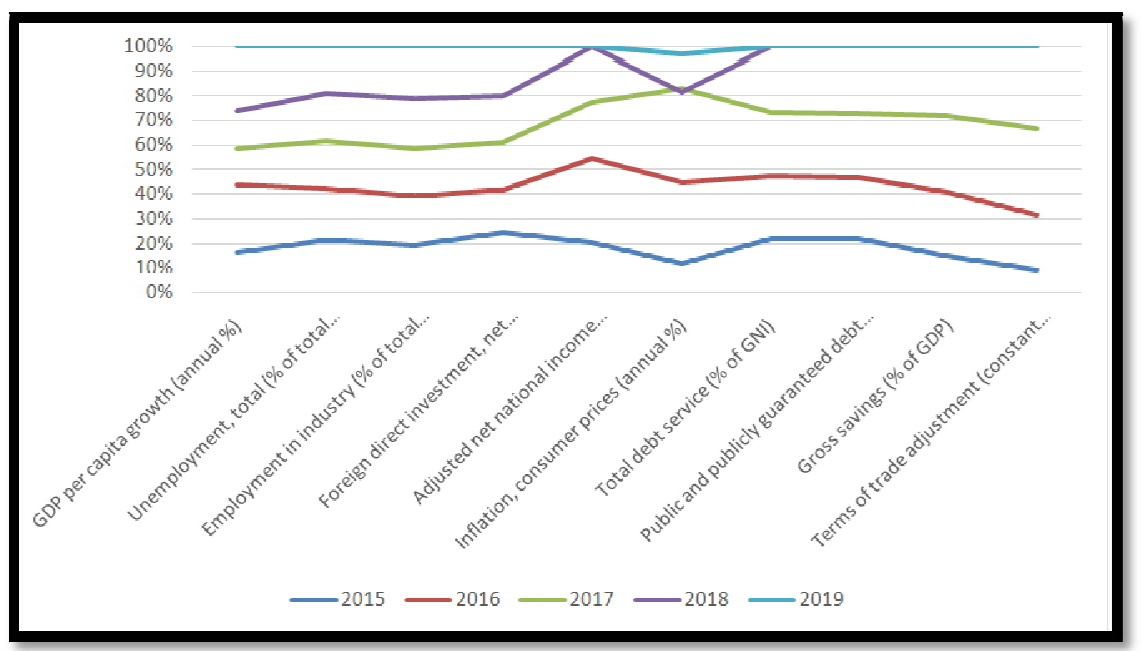

Figure 2: Graphical Representation of Factors Affecting Treasury Bonds in Rwanda (2015-2019)

\subsection{Discussions of the Results}

The research set out the objective to determine the impact of Treasury bond on economic development in Rwanda. The Treasury bond market variables were bond market size (BMS) as a measure of market size and bond market turnover ratio (BMTR) as a measure of market liquidity. The dependent variable adopted was Real Gross Domestic Product (GDP). The researcher, using statistical software SPSS V. 21 analyzed time series data. Analysis was done on two models, one with bond market variables as the only independent variables. Real GDP was the dependent variable in both models. From the correlation analysis findings, both size (BMS) and liquidity (BMTR) variables have significant positive correlation with GDP with BMS having a correlation coefficient of 0.728 . The study is in line with Murayi (2013) who examined the impact of capital market deepening on economic growth in Kenya found that the bond market turnover ratio had a significant positive relationship with the economic growth, suggesting that the bond market is essential contributor to economic growth in Kenya and important for providing financing for key infrastructure projects. Mbewa et al., (2012) carried out a study on the development of the bond 
market in Kenya. The study was carried out through a situational analysis of the bonds market by examining the performance of the market, appropriateness of the institutional set up and the policy development. The study established that Kenya's bond market, at the time, was far from what can be referred to as a developed bond market

\section{Conclusions and Recommendations}

With limited studies focusing on the treasury bonds as determiner of economic growth and the increasing number of individual and institutional investor in the Rwandan bond market, the research objective set out was to determine the impact of Treasury bond market on economic growth in Rwanda. From the findings, both bond market variables of size and liquidity have significant positive relationship with GDP. It can therefore be concluded that Treasury bond market development has a significant positive effect on economic growth in Rwanda.

The study recommends that the Capital Markets Authority should also hasten the introduction of the new products into the capital markets such as derivative instruments (bond options, futures, swaps) and have necessary regulatory framework in place to make the bond market even more vibrant.

\section{References}

i. Adelegan, U. \& Radzewics, B. (2013). Liquidity in an Emerging Bond Market: A Case Study of Corporate Bonds in Malaysia. Bank of International Settlements

ii. Adelman, A. (2010), Stock Markets and Development, European Economic Review, Vol. 37, 632-640.

iii. Bank for International Settlements (BIS). (2012). Transactions costs and investment style: An interexchange analysis of institutional equity trades. Journal of Financial Economics 46:265-92.

iv. BNR (2014), Annual report July 2013-June 2014 - Kigali

v. $\quad$ BNR (2015), Annual report July 2014-June 2015 -Kigali. Central bank of Rwanda

vi. $\quad$ BNR (2016), Annual report July 2015-June 2016 - Kigali

vii. Becker, B., \& Ivashina, V. (2011). Cyclicality of Credit Supply: Firm Level Evidence. Boston:Harvard Business School Press.

viii. Biepke, R. (2014). The Development of the International Bond Market. BIS Economic Papers 32. International Journal of Finance \& Economics, 7(1), 15-35.

ix. CMA (2012). Saving and Investing through Rwanda's Capital Market. Capital Markets in Rwanda: Assessment and Aspirations

x. Fink and Kosekoff, (2011), Stock market development and economic growth evidence from developing countries.

xi. Ghatak K. (2013). Financial Repression, the New Structuralists, and Stabilization Policy in SemiIndustrialized Economies, Journal of Development Economics, April 1984, 305-32.

xii. Glass \& Hopkins, (2013). Financial Factors in Economic Development.' Papers and Proceedings of the Hundred and First Annual Meeting of the American Economic Association, The American Economic Review, Vol. 79, No. 2, (May, 1989), pp. 204-209.

xiii. IMF, (2011). Guidelines for Public Debt Management,(www.imf.org/external/np/pdept/200/eng/index.html).

xiv. Ingham, (2015). Institutional development, financial deepening and economic growth: Evidence from China,'Journal of Banking \& Finance, Jan2009, Vol. 33 Issue 1, p157-170, 14p.

xv. Jensen, B. (2015). Financial development and economic development: international evidence', Economic Development and Cultural Change, 34, 333-46.

xvi. Kapingura, F., \& Makhetha-Kosi, P. (2014). The Causal Relationship between the Bond Market Development and Economic Growth in Africa: Case Study of South Africa. Mediterranean Journal of Social Sciences, 5 (3), 126

xvii. Kazarwa W. (2015). The challenges of emerging stock markets in Africa, a case of Rwanda Stock Exchange. East African Journal of Science and Technology, 5 (1) PP 257- 269.

xviii. Kibua, N. Maina, M. \& Masinde, M. (2015). Prospects for Developing a Regional Bond Market in Eastern Africa. Review of Financial Studies, 2(3), 297-310.

xix. Levine A. \& Zervos B. (2014), Theories of Economic Growth and Development. Stanford: Stanford University Press,

xx. Mathu, (2014). Appraisal of capital market efficiency on economic growth in Rwanda.

xxi. Mbewa, M. Ngugi, R. \& Kithinji A. (2012). Developing of Bond Market: Kenya's Experience. KIPPRA Working Paper, 15

xxii. MINECOFIN, (2013). The annual economic report fiscal year 2012/2013 December 2013

xxiii. Murayi, M. T. (2013). The Effect of Capital Market Deepening on Economic Growth in Kenya. University of Nairobi

xxiv. Mussa, S. \& Kihongo V. (2011) Prospects and Challenges of Treasury bonds Financing in Tanzania. Asian Journal of Business Management 3(3), 178-187, 2011

xxv. Ndung'u, N. (2013). Challenges in developing a successful bond market in Kenya. Remarks by Governor of the Central Bank of Kenya, at the Market Leaders Forum dinner, Nairobi, 6 August 2013. 
xxvi. Ngugi, S. M., \& Afande, F. O. (2015). Raising Finance in the Kenyan Bond Market: A Case of Listed Companies on the Nairobi Stock Exchange. Developing Country Studies, 5 (7).

xxvii. Onwumere J., Ibe I. G., Okafor R. G., \& Uche U. B. (2012). Stock Market and Economic Growth in Nigeria: Evidence from the Demand-Following Hypothesis. European Journal of Business and Management, 4(19), 1-9. R

xxviii. Perkins \& Block, (2012). Financial Development and Economic

xxix. Rajan, William \& Zingales, (2015). 'Stock Markets and Development,' European Rosita P. Chang (eds.), Pacific Basin Capital Markets Research Proceeding of the Second. Annual Pacific Basin Finance Conference, Vol. II, Bangkok, Thailand, 4-6 June, Amsterdam: North Holland. Carvajal, A., Elliott, J.

xxx. Rostow, A. (2011). Stock Market and Economic Development: A Causality Test', The Journal of Nepalese Business Studies, pp: 36-44.

xxxi. Todaro J. \& Smith, M. (2011). Financial intermediary development and growth volatility: do intermediaries dampen or magnify shocks? Journal of International Money and Finance, 25, pp. 1146-1167Winfield, G. \& Curry, S. (2010). Success in Investment, 5th Ed. Boston: John Murray Publishers

xxxii. World Bank (2011), Guidelines for Public Debt Management, (www.imf.org/external/np/pdept/200/eng/index.html). 